\title{
Endogenous hepcidin synthesis protects the distal nephron against hemin and hemoglobin mediated necroptosis
}

\author{
Rachel P. L. van Swelm', Madelon Vos ${ }^{1}$, Frank Verhoeven', Frank Thévenod ${ }^{2}$ and Dorine W. Swinkels ${ }^{1}$
}

\begin{abstract}
Hemoglobinuria is associated with kidney injury in various hemolytic pathologies. Currently, there is no treatment available and its pathophysiology is not completely understood. Here we studied the potential detrimental effects of hemoglobin $(\mathrm{Hb})$ exposure to the distal nephron (DN). Involvement of the DN in $\mathrm{Hb}$ kidney injury was suggested by the induction of renal hepcidin synthesis $(p<0.001)$ in mice repeatedly injected with intravenous Hb. Moreover, the hepcidin induction was associated with a decline in urinary kidney injury markers 24p3/NGAL and KIM1, suggesting a role for hepcidin in protection against $\mathrm{Hb}$ kidney injury. We demonstrated that uptake of $\mathrm{Hb}$ in the mouse cortical collecting duct cells $\left(\mathrm{mCCD}_{\mathrm{cl} 1}\right)$ is mediated by multi-protein ligand receptor $24 \mathrm{p} 3 \mathrm{R}$, as indicated by a significant $90 \%$ reduction in $\mathrm{Hb}$ uptake $(p<0.001)$ after $24 \mathrm{p} 3 \mathrm{R}$ silencing. Moreover, incubation of $\mathrm{mCCD}_{\mathrm{cl} 1}$ cells with $\mathrm{Hb}$ or hemin for 4 or $24 \mathrm{~h}$ resulted in hepcidin synthesis and increased mRNA expression of markers for oxidative, inflammatory and ER stress, but no cell death as indicated by apoptosis staining. A protective role for cellular hepcidin against Hb-induced injury was demonstrated by aggravation of oxidative, inflammatory and ER stress after $4 \mathrm{~h} \mathrm{Hb}$ or hemin incubation in hepcidin silenced $\mathrm{mCCD}_{\mathrm{cl}}$ cells. Hepcidin silencing potentiated hemin-mediated cell death that could be diminished by co-incubation of $\mathrm{Nec}-1$, suggesting that endogenous hepcidin prevents necroptosis. Combined, these results demonstrate that renal hepcidin synthesis protects the DN against hemin and hemoglobin-mediated injury.
\end{abstract}

\section{Introduction}

Reactive forms of iron (Fe), such as heme, are increasingly associated with renal injury ${ }^{1}$. Hemolysis and subsequent hemoglobinuria have been related to renal injury in various pathologies including paroxysmal nocturnal hemoglobinuria, favism and sickle cell anemia, but also as potential post-operative complication of cardiopulmonary bypass $^{2-7}$. Also hematuria has been linked with hemoglobin-induced kidney injury, e.g., in patients with IgA nephropathy ${ }^{4}$. At this moment, there are no specific

Correspondence: Rachel Swelm (Rachel.vanSwelm@radboudumc.nl) ${ }^{1}$ Department of Laboratory Medicine, Radboud university medical center, Radboud Institute for Molecular Life Sciences, Nijmegen, The Netherlands ${ }^{2}$ Institute of Physiology, Pathophysiology \& Toxicology, Center for Biomedical Training and Research, University of Witten/Herdecke, Witten, Germany Edited by A. Finazzi-Agrò preventive measures or therapies for hemoglobin-induced kidney injury.

Hemolysis leads to cell-free circulating hemoglobin $(\mathrm{Hb})$, which can be filtered by the glomerulus and reabsorbed by the megalin endocytic receptor in proximal tubules $(\mathrm{PT})^{8,9}$. Subsequently, heme is liberated from $\mathrm{Hb}$ and exported by the heme exporter FLVCR, used in heme-carrying proteins such as cytochrome P450 enzymes, or converted to bilirubin by heme oxygenase- 1 (HO-1). HO-1-mediated catabolism yields intracellular free and reactive $\mathrm{Fe}^{2+}$, which is converted to $\mathrm{Fe}^{3+}$ by $\mathrm{H}-$ ferritin and stored by L-ferritin or exported by

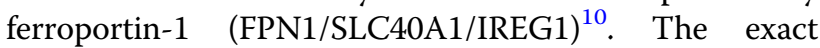
mechanisms underlying $\mathrm{Hb}$-induced kidney injury have not been completely elucidated, but appear to be multifactorial. Oxidative stress plays an important role in tubular damage during hemoglobinuria ${ }^{11}$. Heme redox

\section{(c) The Author(s) 2018}

(c) (i) Open Access This article is licensed under a Creative Commons Attribution 4.0 International License, which permits use, sharing, adaptation, distribution and reproduction cc) in any medium or format, as long as you give appropriate credit to the original author(s) and the source, provide a link to the Creative Commons license, and indicate if changes were made. The images or other third party material in this article are included in the article's Creative Commons license, unless indicated otherwise in a credit line to the material. If material is not included in the article's Creative Commons license and your intended use is not permitted by statutory regulation or exceeds the permitted use, you will need to obtain permission directly from the copyright holder. To view a copy of this license, visit http://creativecommons.org/licenses/by/4.0/. 
A

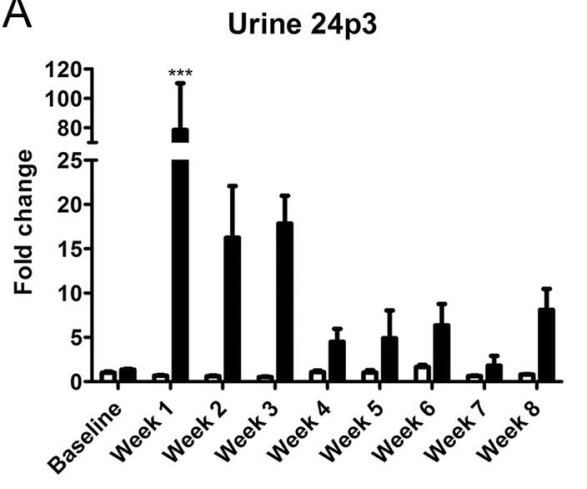

Urine KIM1

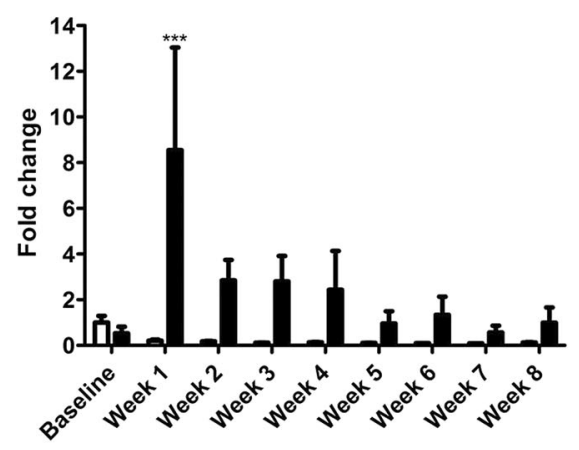

B
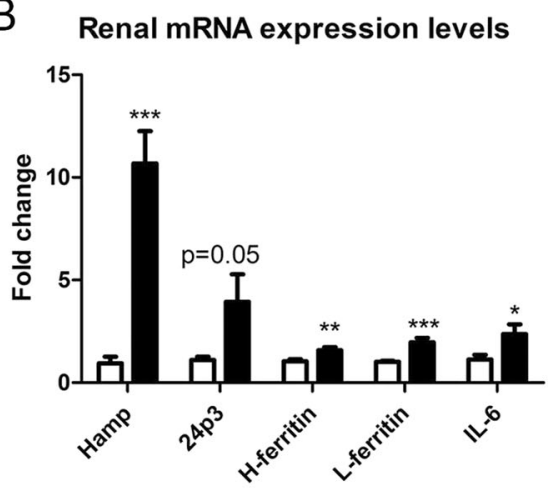

Fig. 1 Kidney injury markers in Hb-treated mice. Mice treated with a weekly i.v. injection of saline (control; $n=5)$ or Hb ( $n=4)$ for 8 weeks demonstrated increased urinary kidney injury markers $24 \mathrm{p} 3$ and KIM1 compared to control (a). Increased renal mRNA expression of Hamp after 8 weeks of $\mathrm{Hb}$ treatment, accompanied by increased IL-6, 24p3, H-ferritin, and L-ferritin (b). Data in panel A was analyzed with Two-way ANOVA with Bonferroni post-hoc test; data in panel B with Student's $t$-test. ${ }^{*}=p<0.05$; ${ }^{*}=p<0.01$; and ${ }^{* *}=p<0.001$ compared to control

cycling between ferric and ferryl states generates radical oxygen species that promote tissue damage if their concentration exceeds the catabolic and antioxidant capacity of $\mathrm{HO}-1^{3}$. Reactive Fe becomes toxic when Fe storage and export capacities of ferritin and FPN1, respectively, are exceeded $^{4}$. Indeed, increased levels of cellular iron may lead to a regulated form of necrosis named ferroptosis ${ }^{12}$. Ferroptosis has been specifically implicated in acute kidney injury and involves glutathione depletion, oxidative stress and lipid peroxidation ${ }^{13-15}$. Renal tissue of guinea pigs with experimental transfusion-related hemolysis showed increased staining of a lipid peroxide marker for oxidative damage to tissue proteins ${ }^{16}$. Also endoplasmic reticulum (ER) stress and subsequent unfolded protein response (UPR) may be involved. Evaluation of the renal gene transcript response in hemolytic guinea pigs unveiled increased expression of UPR genes, which was confirmed by immunostaining of UPR chaperone HSP70 in tubular epithelial cells. This study also revealed increased response of the ER stress pathway of apoptosis to hemoglobinuria. Furthermore, heme-induced renal apoptosis plays an important role in acute renal failure in rats with glycerol-induced rhabdomyolysis ${ }^{17}$. In addition to ferroptosis and apoptosis, heme toxicity has been associated with another form of regulated cell death, called necroptosis, in macrophages, astrocytes, cortical neurons and endothelial cells ${ }^{18-21}$. Necroptosis is regulated via RIPK3 and can be initiated via several triggers, including inflammatory stimuli and ischemia/reperfusion injury ${ }^{22}$. Indeed, heme can trigger an inflammatory response in patients and experimental animal models for hemoglobinuria, which may be mediated by the toll-like receptor 4 (TLR4)/NF-kB pathway and Interleukin-6 $\left(\right.$ IL-6) ${ }^{17,23,24}$.

Molecular interactions of intra-tubular $\mathrm{Hb}$ have predominantly been described for epithelial cells of the PT. However, since $\mathrm{Hb}$ casts have been observed in the distal nephron (DN) after hemolysis ${ }^{9,25-28}$, tubular $\mathrm{Hb}$ excess is also likely to affect the DN. Recently, we observed uptake of fluorescently labeled $\mathrm{Hb}$ in a mouse cortical collecting duct cell line $\left(\mathrm{mCCD}_{\mathrm{cl} 1}\right)$, demonstrating the potential of $\mathrm{Hb}$ to enter epithelial cells of the $\mathrm{DN}^{29}$. In this study, the molecular mechanism of $\mathrm{Hb}$ uptake was not elucidated, but it has been shown that proteins are reabsorbed in DN segments via the multi-protein ligand 24p3/NGAL/lipocalin-2 receptor (24p3R; SLC22A17) in case PT are 


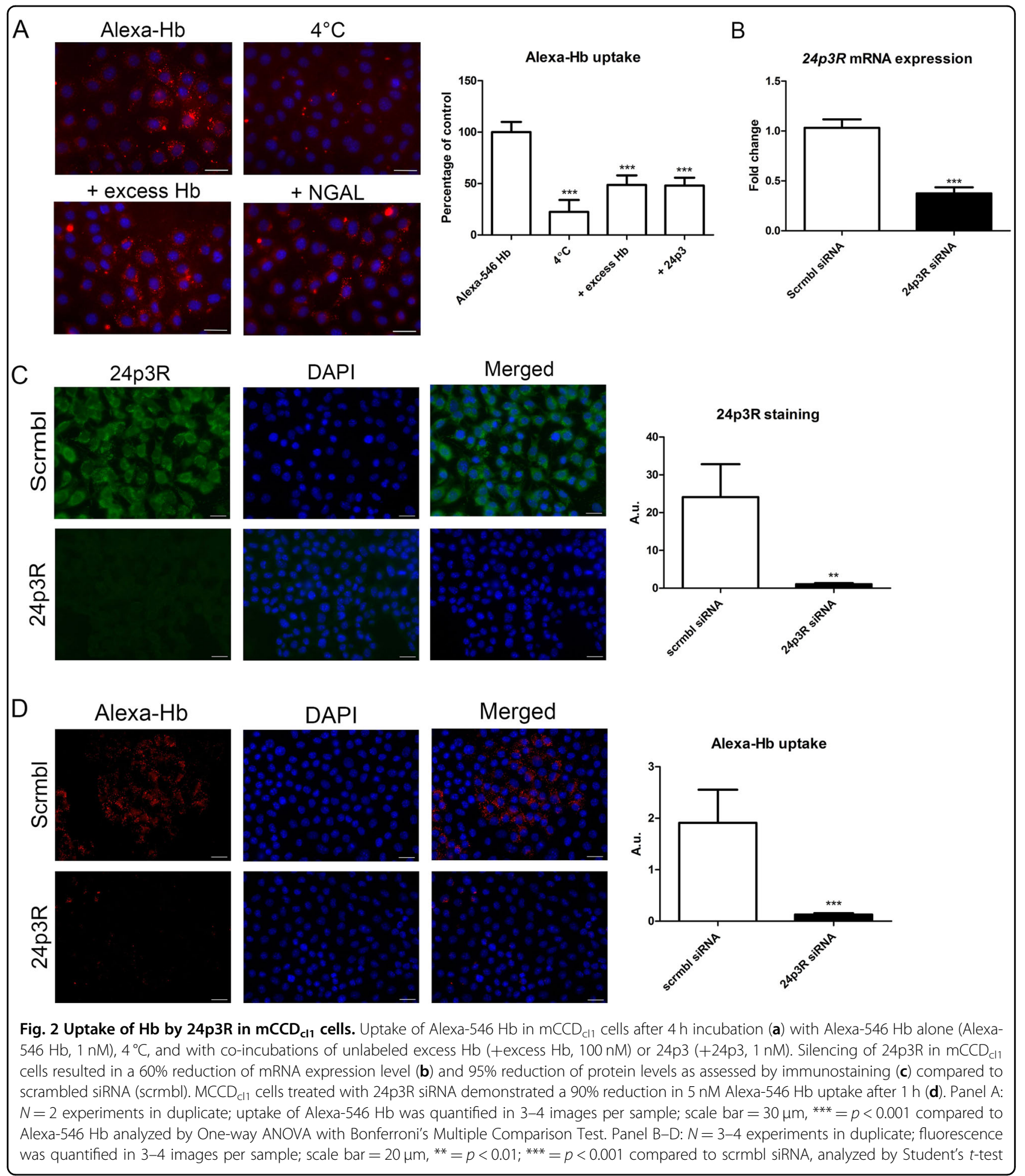

overwhelmed $^{30,31}$. The $24 \mathrm{p} 3$ receptor mediates endocytosis of free and Fe-bound $24 \mathrm{p} 3^{32-34}$, but also facilitates endocytic uptake of other Fe-containing ligands, such as Fe-binding proteins, including transferrin, albumin or methallothionin ${ }^{30,31}$.
Data from multiple clinical observational and experimental studies suggest that the Fe-regulatory hormone hepcidin may protect against heme-mediated kidney injury $^{29,35-38}$. Interestingly, it was the amount of hepcidin present in urine, and not blood, that associated with 
reduced risk for kidney injury in patients undergoing cardiopulmonary bypass ${ }^{35,36}$. Since all patients had similarly elevated blood hepcidin concentrations ${ }^{37}$, the differentially increased amount of hepcidin in urine could be explained by local renal production. Indeed, hepcidin is synthesized in the kidney, specifically in the $\mathrm{DN}^{29,39,40}$.

The present study was conducted to get more insight in the molecular pathways that are involved in renal $\mathrm{Hb}$ handling and subsequent injury in the DN and the potential modification of these processes by locally synthesized hepcidin.

\section{Results}

Repeated $\mathrm{Hb}$ administration in mice results in increased renal hepcidin synthesis and adaptation to renal injury

C57Bl/6 mice were injected with i.v. Hb once weekly for 8 weeks to study the effect on renal hepcidin synthesis in relation to injury. After each $\mathrm{Hb}$ injection, urine was collected to assess urinary kidney injury markers 24p3/ NGAL and kidney injury molecule 1 (KIM1). Urinary levels of 24p3 and KIM1 were significantly elevated in $\mathrm{Hb}$ treated mice after the first injection (Fig. 1a), indicating early $\mathrm{Hb}$-induced kidney injury. The levels of both injury

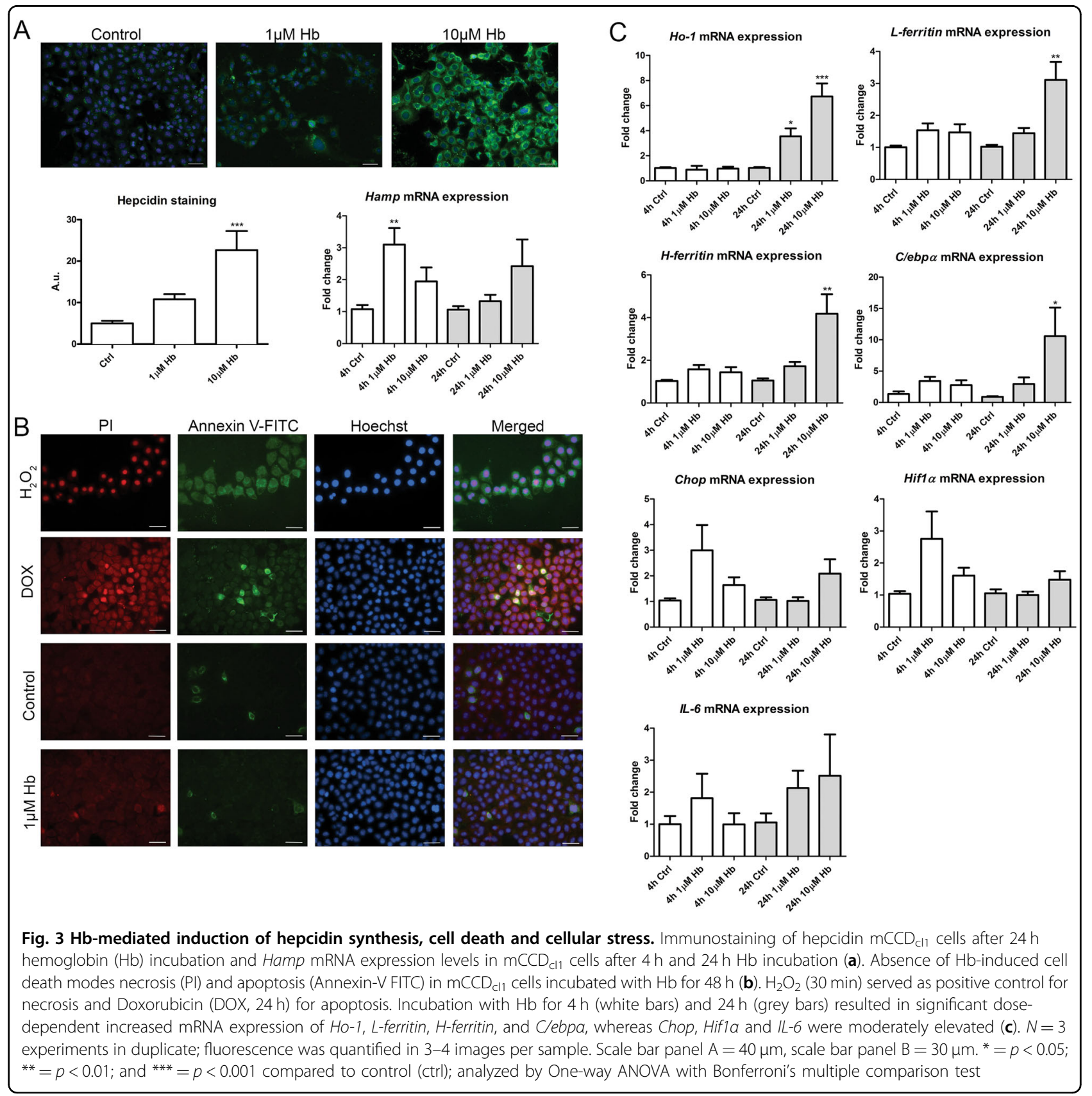


markers subsequently declined over time, but remained elevated compared to control. Renal mRNA expression levels of $24 p 3(p=0.05), H$-ferritin $(p<0.01), L$-ferritin $(p<0.001)$, and $I L-6(p<0.05$; Fig. $1 \mathrm{~b})$, measured at the end of the study were increased. Moreover, renal mRNA expression levels of hepcidin (Hamp) were increased 10fold in Hb-treated mice $(p<0.001)$ compared to control, which, in view of the known localization of renal hepcidin production ${ }^{29,39,40}$, demonstrates involvement of the $\mathrm{DN}$. The presumed protective effects of hepcidin against $\mathrm{Hb}$ induced renal injury ${ }^{29,35-38}$ may even suggest that local hepcidin synthesis prevented $\mathrm{Hb}$-induced kidney injury.

\section{$\mathrm{Hb}$ is taken up via $24 \mathrm{p} 3 \mathrm{R}$ in $\mathrm{mCCD_{ \textrm {cl } 1 }}$ cells}

We investigated the role of $24 \mathrm{p} 3 \mathrm{R}$ in $\mathrm{Hb}$ uptake in $\mathrm{mCCD}_{\mathrm{cl} 1}$ cells by competitive inhibition using fluorescently labeled $\mathrm{Hb}$ (Alexa-546 $\mathrm{Hb}$ ). Non-specific binding of Alexa546-Hb was assessed by incubation at $4{ }^{\circ} \mathrm{C}$. Excess unlabeled $\mathrm{Hb}(100 \mathrm{nM})$ was used to determine $\mathrm{Hb}$ specific uptake, and $24 \mathrm{p} 3(1 \mathrm{nM})$, the natural high affinity ligand of $24 \mathrm{p} 3 \mathrm{R}^{41}$, to study $24 \mathrm{p} 3 \mathrm{R}$-specific uptake. Both significantly reduced uptake of Alexa546- $\mathrm{Hb}$ in $\mathrm{mCCD}_{\mathrm{cl} 1}$ cells (both $p<0.001$; Fig. 2a).

Next, 24p3R was silenced by siRNA to functionally determine its contribution to $\mathrm{mCCD}_{\mathrm{cl} 1} \mathrm{Hb}$ uptake. Silencing of $24 \mathrm{p} 3 \mathrm{R}$ for $72 \mathrm{~h}$ reduced $24 \mathrm{p} 3 \mathrm{R}$ mRNA expression by $60 \%(p<0.001)$ and $24 \mathrm{p} 3 \mathrm{R}$ protein level by
95\% $(p<0.01)$ as assessed by immunofluorescence staining (Fig. 2b-c), compared to scrambled siRNA. Incubation with Alexa- $546 \mathrm{Hb}$ for $1 \mathrm{~h}$ demonstrated a $90 \%$ reduction in $\mathrm{Hb}$ uptake in $24 \mathrm{p} 3 \mathrm{R}$ silenced $\mathrm{mCCD}_{\mathrm{cl} 1}$ cells $(p<0.001$; Fig. $2 \mathrm{~d}$ ), indicating that $24 \mathrm{p} 3 \mathrm{R}$ is the major route of $\mathrm{mCCD}_{\mathrm{cl} 1} \mathrm{Hb}$ uptake.

\section{$\mathrm{Hb}$ and hemin induce hepcidin synthesis and intracellular cell stress in $\mathrm{mCCD}_{\mathrm{cl} 1}$}

Dose-dependent hepcidin synthesis was evident in $\mathrm{mCCD}_{\mathrm{cl} 1}$ cells after $24 \mathrm{~h}$ incubation with $\mathrm{Hb}$ on protein level $(p<0.001$ for $10 \mu \mathrm{M})$ and after $4 \mathrm{~h}$ of $\mathrm{Hb}$ incubation on mRNA expression level $(p<0.01$ for $1 \mu \mathrm{M}$; Fig. 3a). Cell death by propidium iodide (PI) and Annexin V-FITC staining was not observed when cells were incubated with $\mathrm{Hb}$ for $48 \mathrm{~h}$ (Fig. 3b). Despite the absence of cell death, $\mathrm{Hb}$ incubations of 4 and $24 \mathrm{~h}$ led to cellular stress as indicated by mRNA expression levels of various markers (Fig. 3c). The significant and dose-dependent induction of $\mathrm{Ho}-1$ mRNA at $24 \mathrm{~h}(p<0.05$ for $1 \mu \mathrm{M} ; p<0.001$ for $10 \mu \mathrm{M})$ revealed $\mathrm{Hb}$ catabolism, whereas the induction of $H$ and $L$-ferritin mRNA at $24 \mathrm{~h}$ (both $p<0.01$ for $10 \mu \mathrm{M}$ ) suggested increased intracellular Fe handling and storage. Expression of CCAAT/enhancer-binding protein $\alpha(\mathrm{C} /$ ebp $\alpha)$ mRNA, a transcription factor reported to induce hepcidin synthesis in hepatocytes ${ }^{42}$, was significantly elevated after $24 \mathrm{~h} \mathrm{Hb}$ incubation $(p<0.05$ for $10 \mu \mathrm{M})$.

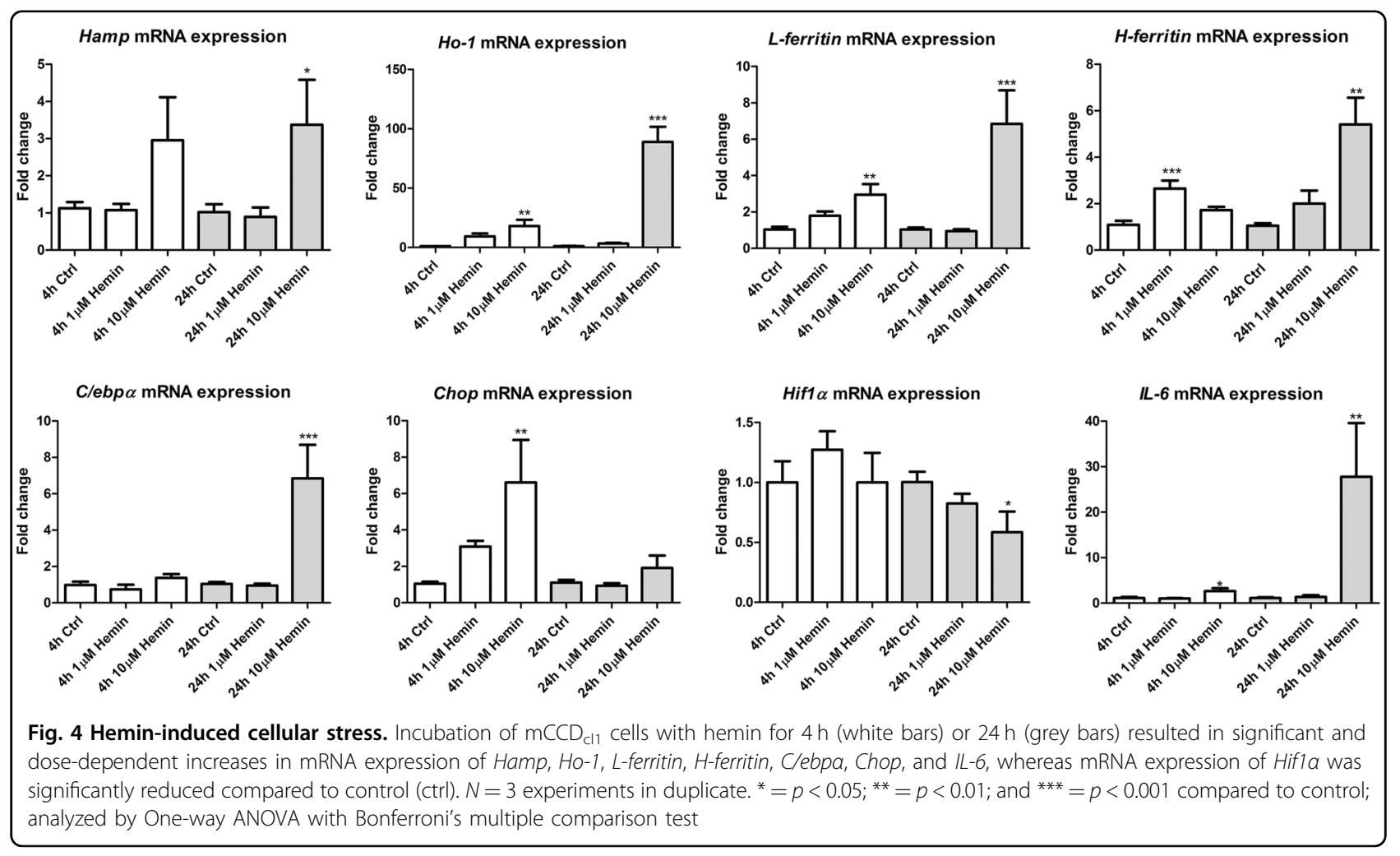


Also mRNA expression levels of C/ebp homologous protein (Chop), Hypoxia inducible factor $1 \alpha(\mathrm{Hif} 1 \alpha)$ and IL-6 were increased, although not significantly, which might hint towards ER stress, oxidative stress and inflammation, respectively ${ }^{43,44}$. Overall, most cell stress markers were induced already after $4 \mathrm{~h}$ of $\mathrm{Hb}$ incubation, some of which became statistically significant after $24 \mathrm{~h}$ (Ho-1, H-ferritin, L-ferritin, C/ebp $\alpha$ ). Combined these results demonstrated that $\mathrm{Hb}$ is catabolized in $\mathrm{mCCD}_{\mathrm{cl} 1}$ cells and induces cellular stress, but does not lead to cell death

To investigate whether cellular stress is caused by the Fe-containing heme component of $\mathrm{Hb}, \mathrm{mCCD}_{\mathrm{cl} 1}$ cells were incubated with 1 or $10 \mu \mathrm{M}$ hemin for $4 \mathrm{~h}$ and $24 \mathrm{~h}$ (Fig. 4). Hamp mRNA expression was induced after $4 \mathrm{~h}$ and $24 \mathrm{~h}$ after $10 \mu \mathrm{M}$ ( $p<0.05$ for $24 \mathrm{~h})$. In concurrence, $10 \mu \mathrm{M}$ hemin incubation for $24 \mathrm{~h}$ resulted in significantly induced mRNA expression levels of IL-6 ( $p<0.01)$, Ho-1 $(p<0.001), L$-ferritin $(p<0.001), H$-ferritin $(p<0.01)$, and C/ebpa $(p<0.001)$, and reduced Hif1 $\alpha$ mRNA expression $(p<0.05)$. Since hemin is readily taken up by the cell and quickly catabolized by $\mathrm{HO}-1^{45}$, we expected to find significant effects on Fe metabolism and cell stress markers already at $4 \mathrm{~h}$ after exposure. Indeed, mRNA expression of Ho-1, L-ferritin, Chop, and IL-6 were all significantly elevated after $4 \mathrm{~h}$ of $10 \mu \mathrm{M}$ hemin incubation, whereas $H$ ferritin was increased by $1 \mu \mathrm{M}$ hemin.

Silencing of hepcidin in $\mathrm{mCCD}_{\mathrm{cl} 1}$ cells aggravates cellular stress and induces apoptosis in response to $\mathrm{Hb}$ and hemin

Hamp siRNA was used to silence hepcidin, with Renilla luciferase (RLUC) siRNA as negative control. Hamp mRNA expression levels were lowered by $85 \%$ in Hamp siRNA treated cells compared to RLUC controls $(p<$ 0.001; Fig. 5a). Surprisingly, Hamp silencing also significantly reduced $I L-6 \quad(p<0.001)$ and Chop $(p<0.01)$ mRNA expression, suggesting that hepcidin exerts a physiological signaling function in $\mathrm{mCCD}_{\mathrm{cl} 1}$ homeostasis. We analyzed the effect of Hamp silencing on $\mathrm{Hb}$ and hemin induced oxidative stress by CellRox Green staining after $4 \mathrm{~h}$ incubation (Fig. 5b). Interestingly, untreated Hamp silenced $m C C D_{\text {cl1 }}$ cells had higher oxidative stress levels compared to RLUC controls. Incubation with $1 \mu \mathrm{M}$ hemin induced significantly more oxidative stress in Hamp silenced cells compared to RLUC controls $(p<$ $0.001)$ and untreated Hamp silenced cells $(p<0.01)$. Surprisingly, oxidative stress was significantly reduced in Hamp silenced cells treated with $1 \mu \mathrm{M}$ Hb compared to untreated cells $(p<0.001)$. However, since the oxidative stress levels also dose-dependently decreased in both $\mathrm{Hb}$ and hemin-treated RLUC controls, in both conditions these reductions may reflect an adaptive response caused by antioxidant mechanisms. Then, cell death was assessed by means of Annexin V and PI FACS analysis in Hamp silenced $\mathrm{mCCD}_{\mathrm{cl} 1}$ cells exposed to $4 \mathrm{~h} 10 \mu \mathrm{M} \mathrm{Hb}$ and hemin (Fig. 6). Annexin V was similarly significantly induced by hemin exposure, but not $\mathrm{Hb}$ exposure, in RLUC and Hamp silenced cells $(p<0.001)$. PI was not increased by $\mathrm{Hb}$, but hemin exposure significantly increased PI in Hamp silenced cells compared to control $(p<0.05)$, but not in RLUC silenced cells. The heminmediated induction of PI was significantly reduced to control levels by co-incubation of Nec-1, an inhibitor of necroptosis, whereas co-incubation with an inhibitor for apoptosis (zVAD-fmk) or ferroptosis (Fer-1) had no effect. Moreover, none of the inhibitors had any effect on the hemin-induced Annexin V induction.

Finally, we analyzed mRNA expression levels of the markers for $\mathrm{Fe}$ metabolism and intracellular stress in RLUC and Hamp silenced cells in response to $4 \mathrm{~h} \mathrm{Hb}$ and hemin incubation (Fig. 7). Hamp silencing resulted in higher Ho- 1 and $I L-6$ induction after both $\mathrm{Hb}$ and hemin treatment compared to RLUC controls with the same treatment. Increased Hif1 $\alpha$ mRNA expression levels in Hamp silenced cells in response to $\mathrm{Hb}$ and hemin support increased oxidative stress as observed by CellRox green staining. Conversely, the induction of C/ebp $\alpha$ in RLUC controls as a result of $\mathrm{Hb}$ and hemin exposure was abolished in Hamp silenced $\mathrm{mCCD}_{\mathrm{cl} 1}$ cells, which may be the result of the concurrently increased Chop expression, an inhibitor of $C / \mathrm{ebp \alpha}^{46} . L$ and $H$-ferritin mRNA expression levels were increased in Hb-treated Hamp silenced cells, but not with hemin incubation. Together, these results demonstrate increased oxidative, inflammatory and ER stress after $\mathrm{Hb}$ and hemin exposure in Hamp silenced $\mathrm{mCCD}_{\mathrm{cl} 1}$ cells leading to cell death characterized as necroptosis, with more pronounced effects of hemin compared to $\mathrm{Hb}$.

\section{Discussion}

Hemoglobinuria is associated with kidney injury in many pathologies involving hemolysis. Our knowledge of renal $\mathrm{Hb}$ handling and the molecular mechanisms involved in its potential toxicity is incomplete and mostly focused on the PT. Here, we assessed that Hb may also be taken up in the DN through 24p3R and is able to cause cellular stress. Moreover, we demonstrated that local hepcidin synthesis possibly protects against $\mathrm{Hb}$-induced injury.

Our results suggest that hemoglobinuria not only affects the PT, known to facilitate bulk protein reabsorption, but can also reach the $\mathrm{DN}$, since (i) $\mathrm{Hb}$ casts have been observed in the $\mathrm{DN}$ lumen ${ }^{9,25-28}$, (ii) $\mathrm{Hb}$ injections in mice increased renal hepcidin synthesis located in the $\mathrm{DN}$, (iii) $\mathrm{Hb}$ can be taken up in the cortical collecting duct cells through $24 \mathrm{p} 3 \mathrm{R}$ and, (iv) $\mathrm{Hb}$ exposure causes cellular stress in cortical collecting duct cells. The detrimental effects of $\mathrm{Hb}$ exposure observed in $\mathrm{mCCD}_{\mathrm{cl} 1}$ cells are likely the result of heme catabolism 

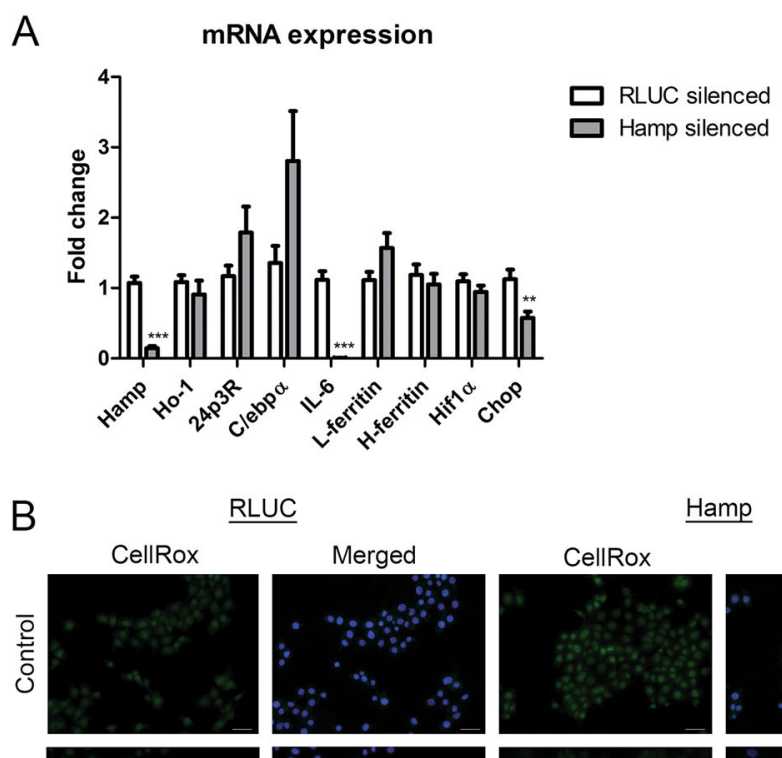

Merged

Hamp
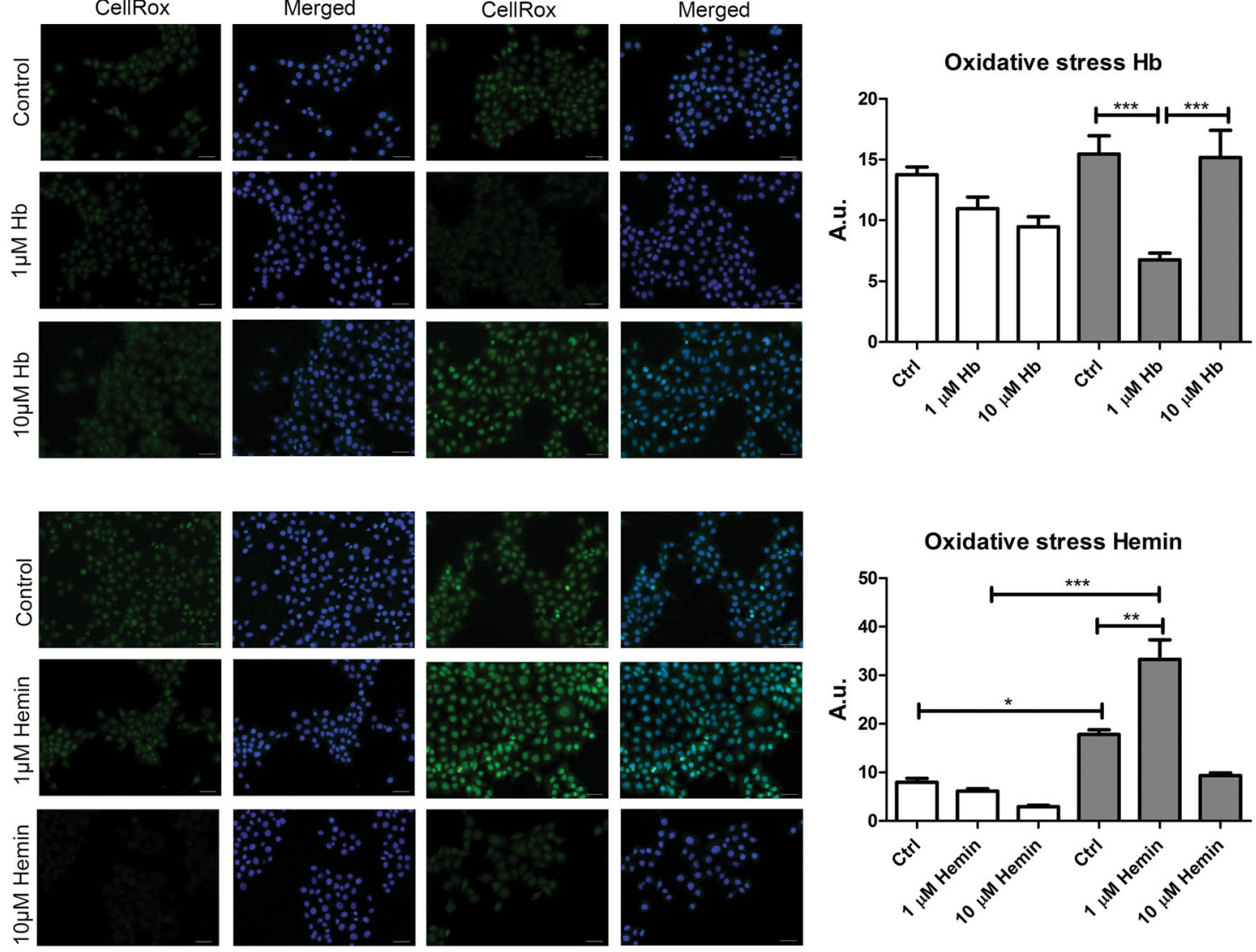

Fig. 5 Cellular stress after hepcidin silencing in $\mathbf{m C C D}_{\mathbf{c l} 1}$ cells. $M C C_{\mathrm{cl} 1}$ cells treated with Hamp siRNA demonstrate a $90 \%$ reduction in Hamp mRNA expression level compared to their negative controls treated with RLUC siRNA (a). Expression levels of IL-6 and Chop are also significantly reduced. Hamp silenced $\mathrm{mCCD}_{\mathrm{cl1}}$ cells (grey bars) show increased baseline oxidative stress (b) compared to RLUC silenced cells (white bars) and enhanced oxidative stress response after $4 \mathrm{~h}$ incubation with $\mathrm{Hb}(10 \mu \mathrm{M})$ or hemin $(1$ and $10 \mu \mathrm{M})$. Panel $\mathrm{A}: N=6$ experiments in duplicate; panel B: $N=2$ experiments in duplicate. CellRox green fluorescence was quantified in 3-4 images per sample. Scale bar $=40 \mu \mathrm{m}$, merged $=$ CellRox + DAPI. ${ }^{*}=p<0.05 ;{ }^{* *}=p<0.01 ;$ and ${ }^{* * *}=p<0.001$; data in panel A was analyzed by Student's $t$-test, data in panel B by One-way ANOVA with Bonferroni's multiple comparison test

and subsequent Fe liberation as indicated by the similar, but more pronounced, results obtained after hemin incubation. Although hemin can be readily catabolized by $\mathrm{HO}-1^{45}$, which was induced after hemin incubation, we cannot rule out the possibility that hemin affects other pathways. Heme can trigger an inflammatory response by activating TLR4 signaling ${ }^{47}$, as observed in endothelial cells during intravascular hemolysis in a murine model of sickle cell disease ${ }^{48}$. In addition, TLR4 was detected in mouse DN by in situ-hybridization ${ }^{49}$. 


\section{Annexin V}

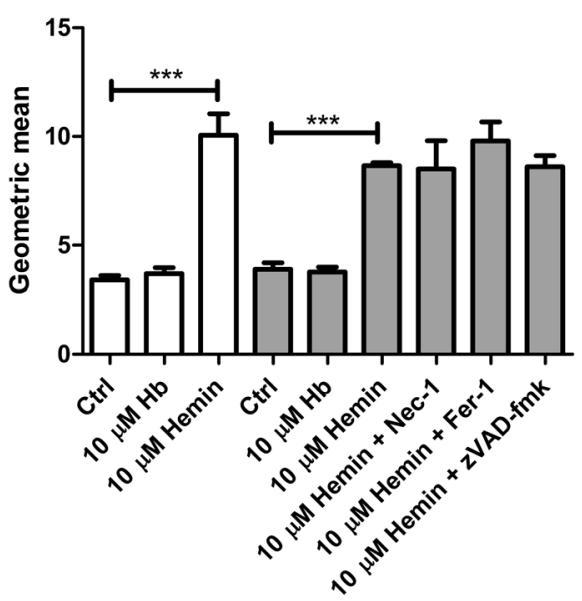

PI

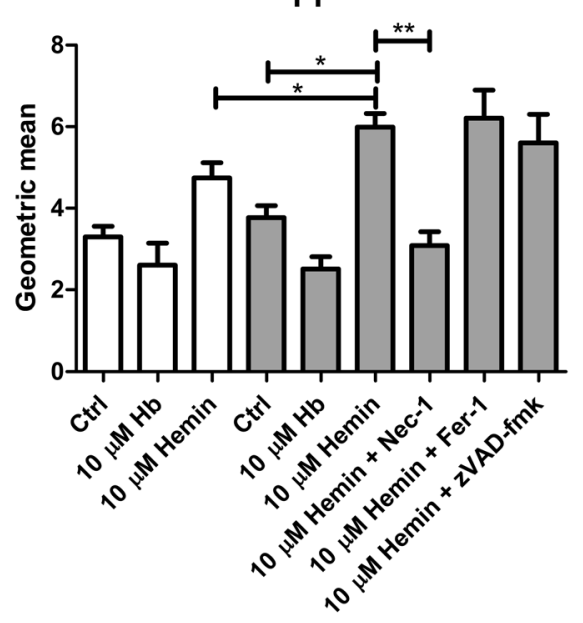

Fig. 6 Hemin-induced necroptosis in hepcidin silenced $\mathbf{m C C D}_{\mathbf{c l} 1}$ cells. Incubation with hemin for $4 \mathrm{~h}$ resulted in similarly increased Annexin $\mathrm{V}$ FITC signal in both RLUC (white bars) and Hamp silenced (grey bars) mCCD $_{\mathrm{cl} 1}$ cells, whereas PI was more increased in Hamp silenced mCCD cl1 $_{\text {cells. }}$ Co-incubation with the necroptosis inhibitor Nec-1, but not with ferroptosis inhibitor Fer-1 or apoptosis inhibitor zVAD-fmk, reduced hemin mediated PI signal in Hamp silenced cells, indicating necroptosis. $N=3-4$ experiments in duplicate. ${ }^{*}=p<0.05$; ${ }^{* *}=p<0.01$; and ${ }^{* * *}=p<0.001$, analyzed by one-way ANOVA with Bonferroni's multiple comparison test

Nevertheless, it has been demonstrated by Nath et al. that the nephrotoxicity of heme is not solely attributable to TRL4 signaling ${ }^{50}$.

The absence of cell death in $\mathrm{Hb}$ and hemin treated $\mathrm{mCCD}_{\mathrm{cl} 1}$ cells may be explained by the cellular synthesis of hepcidin, suggested to protect against $\mathrm{Hb}$-mediated kidney injury ${ }^{29,35-38}$. Indeed, siRNA knockdown of hepcidin greatly potentiated the detrimental effects of $\mathrm{Hb}$ and hemin in terms of cellular stress and cell death. The proposed mechanisms involved in $\mathrm{Hb}$ handling, $\mathrm{Hb}$ injury and hepcidin-mediated protection have been summarized in Fig. 8. Interestingly, Hamp silencing alone already reduced $I L-6$ and $C H O P$ mRNA expression and increased oxidative stress compared to RLUC silenced cells. This may indicate that hepcidin fulfills an important physiological function in $\mathrm{mCCD}_{\mathrm{cl} 1}$ cells and that silencing of hepcidin may consequently result in cell stress, even without an external trigger. Since only Nec-1 was able to inhibit the hemin-induced cell death as indicated by PI in Hamp silenced cells, we postulate that the mechanism of cell death involved in our experiments is necroptosis. Whereas detrimental effects of iron toxicity have been related to ferroptosis ${ }^{13,14,51}$, toxic effects of heme and hemoproteins have been specifically associated with necroptosis ${ }^{18-21,52}$. In our study, the induction of HO-1, L-ferritin and $\mathrm{H}$-ferritin and increased levels of intracellular oxidative stress in hamp silenced cells would suggest increased yield of reactive iron from heme, which could have led to mechanisms of cell death characterized as ferroptosis. Although it has been demonstrated that $\mathrm{Nec}-1$ has anti-ferroptotic effects $^{22}$, the lack of response on PI signal after coincubation with Fer-1, suggests necroptosis rather than ferroptosis to be involved in our experiments. Nevertheless, it has been reported that both ferroptosis and necroptosis may be involved in a single pathology ${ }^{14,15,53}$. $\mathrm{Hb}$ and hemin mediated cell stress involve processes that have been associated with both ferroptosis (oxidative stress $^{13}$, ER stress ${ }^{54}$ ) and necroptosis (inflammation ${ }^{22}$, ER stress ${ }^{55}$ ), which might suggest that both forms of regulated cell death may be involved. We have only investigated the effects of hemin induced cell death in Hamp silenced cells after $4 \mathrm{~h}$ of hemin exposure. In this time window, only hemin, but not $\mathrm{Hb}$, resulted in cell death. Possibly, the necroptosis observed in this time window is induced by heme directly, either via TLR4, as indicated by $I L-6$ upregulation, or ER stress as indicated by Chop induction, whereas longer exposure to hemin or $\mathrm{Hb}$ would yield excessive amounts of intracellular radical iron that leads to ferroptosis as a result of oxidative stress and lipid peroxidation. Indeed, mixed ferroptosis and necroptosis has been observed in human primary cortical neurons exposed to hemin ${ }^{56}$.

Irrespective of the mechanisms of cell death, our findings agree with previous studies that hepcidin has protective effects on iron-related cell death. Hsieh et al. found that local hepcidin synthesis was needed to abolish $\mathrm{Fe}^{2+-}$ induced apoptosis in human cardiomyocytes, possibly through regulation of GATA-4 and $\mathrm{Bcl}-2^{57}$. Reduced renal tubular apoptosis was also observed in a mouse model of ischemia-reperfusion kidney injury after use of a hepcidin-inducing furin inhibitor ${ }^{58}$. Alternatively, 


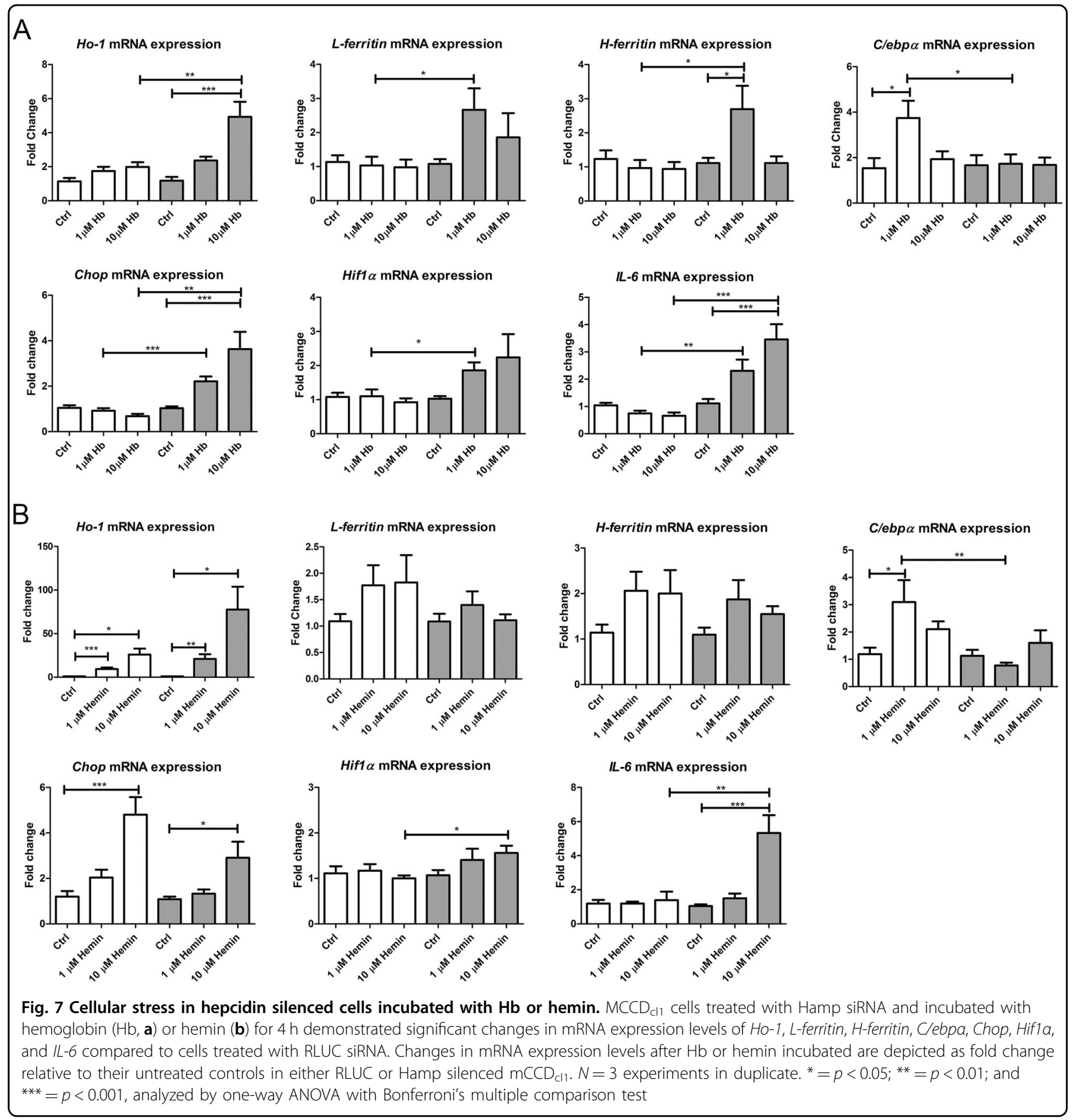

it has been suggested that hepcidin may act as a chelator for reactive $\mathrm{Fe}^{59-61}$. Furthermore, systemically administered hepcidin was shown to reduce inflammation in $\mathrm{Hb}$-treated mice ${ }^{29}$ and oxidative stress in murine ischemia/reperfusion kidney injury ${ }^{38}$. Since many of these stress pathways are intertwined it is difficult to determine the exact mechanism(s) involved, which may differ between locally synthesized and circulating hepcidin.
It remains to be elucidated what initiates hepcidin synthesis in response to $\mathrm{Hb}$ or heme. We found an upregulation of C/ebp $\alpha$, which could be induced during $\mathrm{Hb}$ or heme exposure through IL- 6 or $\mathrm{TNFa}^{62,63}$, but other mechanisms involved in $\mathrm{Hb}$ and heme catabolism could be responsible for hepcidin induction. For instance, oxidative stress can result in hepcidin induction through $\mathrm{H}_{2} \mathrm{O}_{2}$ as demonstrated in hepatocytes ${ }^{64}$. Moreover, heme-induced oxidative stress triggers 


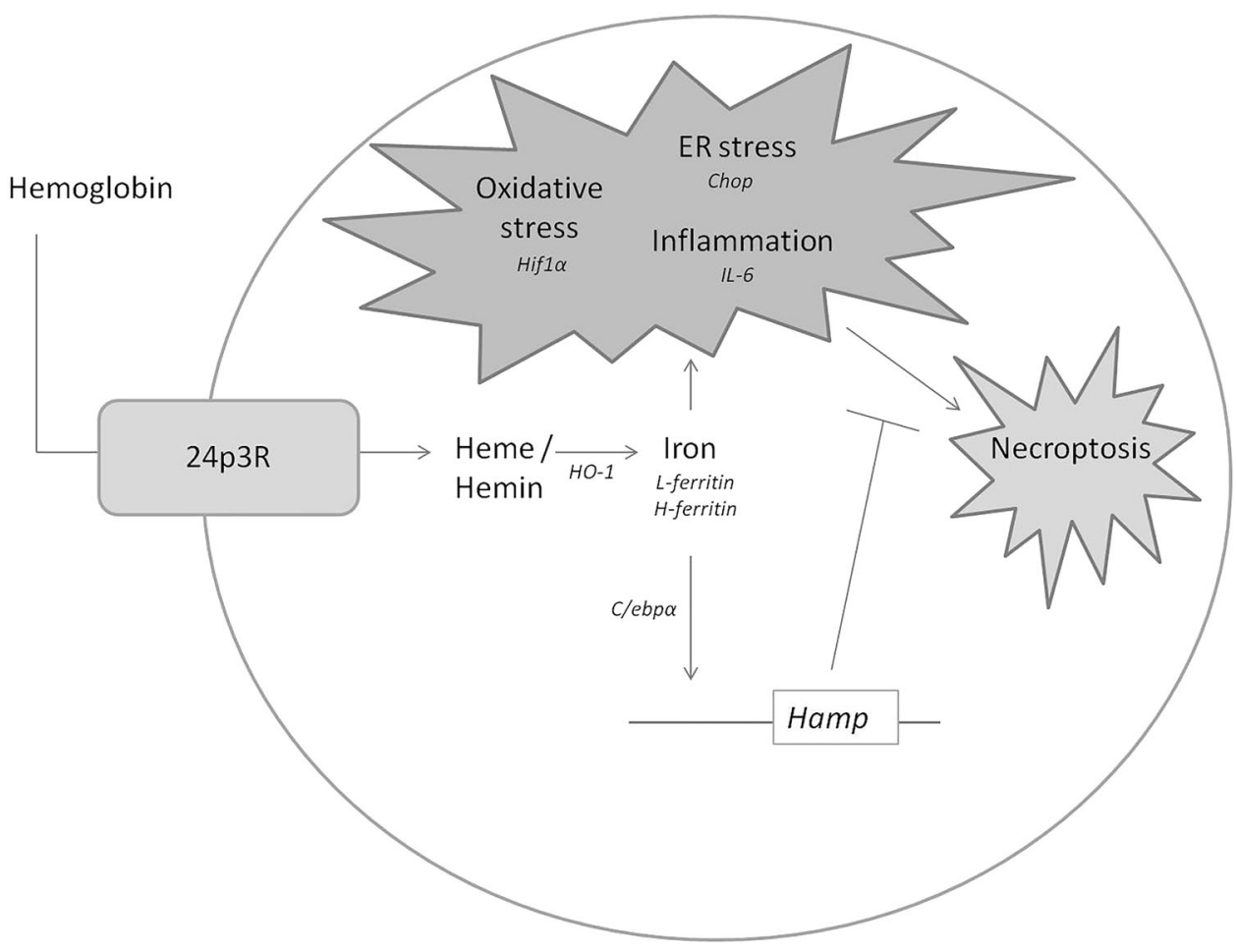

Fig. 8 Schematic representation of the proposed mechanisms involved in hepcidin-mediated protection against heme-mediated injury in $\mathbf{m C C D}_{\mathbf{c l 1}}$ cells. The results suggest that $\mathrm{Hb}$ is taken up via the $24 \mathrm{p} 3 \mathrm{R}$ in $\mathrm{mCCD} \mathrm{cl}_{11}$ cells, after which the heme-group is liberated and catabolized by HO-1 to yield reactive iron. Initially, reactive iron is metabolized and safely stored (H-ferritin and L-ferritin), but when intracellular iron levels exceed the capacity for safe storage, excess iron may cause inflammation (IL-6), oxidative stress (Hifla) and ER stress (Chop). These deleterious pathways can all lead to necroptosis, but simultaneous induction of hepcidin (Hamp) synthesis, possibly via Clebpa, prevents cell death. The gene products typed in Italic represent the markers measured in the study

antioxidant responses via $\mathrm{Nrf2}$, which controls $\mathrm{HO}-1$ expression $^{65}$, but can also trigger hepcidin synthesis, as was shown for phytoestrogens-induced hepcidin activation in hepatocytes ${ }^{66}$. The ER-stress activated transcription factor CREBH can induce hepcidin synthesis by binding to and transactivating the hepcidin promoter in response to toxins or accumulation of unfolded proteins ${ }^{67}$. Finally, inflammation via IL-6 is known to upregulate systemic hepcidin synthesis ${ }^{68}$, and during hemoglobinuria, heme can evoke an IL-6 response through NF- $\mathrm{B}$ B that could, by analogy, elicit renal hepcidin synthesis ${ }^{4,69}$.

In conclusion, the results of our study indicate that the DN may play a far more important role in hemoglobinuria than previously assumed in terms of $\mathrm{Hb}$ handling and hepcidin synthesis. We advocate studies aiming to unravel the combination and sequence of molecular mechanisms sparked by renal epithelial cells of the proximal and distal tubular segments during hemoglobinuria, which will be essential for a better understanding of the events leading to kidney injury and will define approaches to find preventive or therapeutic measures against $\mathrm{Hb}$-induced renal injury.

\section{Materials and methods}

\section{Animal studies}

All experiments were approved by the local Animal Welfare Committee of the Radboudumc (Nijmegen, the Netherlands; DEC 2012-293) in accordance with the guidelines of the Principles of Laboratory Animal Care (NIH publication 86-23, revised 1985). Male C57Bl/6 N mice (Charles River) of 8-11 weeks of age were housed under controlled conditions with pulverized standard chow and water ad libitum and randomly assigned to a treatment group.

Human Hb (Sigma-Aldrich, the Netherlands) was dissolved in saline $(20 \mathrm{mg} / \mathrm{mL})$ and injected via the tail vein, $250 \mu \mathrm{L} /$ mouse, weekly for 8 weeks. $24 \mathrm{~h}$ urine samples were collected at baseline or immediately after each $\mathrm{Hb}$ injection. Kidney tissue was collected in liquid nitrogen and stored at $-80{ }^{\circ} \mathrm{C}$ or in $4 \%$ formalin $\mathrm{O} / \mathrm{N}$ before imbedding in paraffin. 


\section{Enzyme-linked immunosorbent assay (ELISA)}

The concentration of $24 \mathrm{p} 3$ and KIM1 were determined in urine samples using the DuoSet ELISA development kits from R\&D systems (DY1857 and DY1817) according to manufacturer's protocol.

\section{Cell culture}

The $\mathrm{mCCD}_{\mathrm{cl} 1}$ cell line was established by Rossier et al. and cultured as described. Cells were used for experiments between passage 26 and $34^{70}$.

Human $\mathrm{Hb}$ (Sigma-Aldrich, the Netherlands) was labeled with an Alexa Fluor 546 protein labeling kit (Invitrogen), according to manufacturer's instructions. Cells were grown on glass cover slides and incubated with 1-5 nM Alexa-546 labeled $\mathrm{Hb}$ (Alexa-Hb), unlabeled $\mathrm{Hb}$ (100 nM; Sigma-Aldrich) and 24p3 (mouse, $1 \mathrm{nM}$; Enzo Life Sciences) in serum free medium. Hb was dissolved in PBS and hemin in sterile water (supplemented with final concentrations of $50 \mathrm{mM} \mathrm{NaOH}$ and $250 \mathrm{mM}$ Tris base; all Sigma-Aldrich), both used at final concentrations of 1 and $10 \mu \mathrm{M}$.

For silencing, cells were transfected using Lipofectamine RNAiMAX (Invitrogen) according to manufacturer's instructions and siRNA against 24p3R or negative control (scrambled; both $25 \mathrm{nM}$ ), and against hepcidin (EMU174481) or negative control against renilla luciferase (RLUC; EHURLUC, both SigmaAldrich) at $10 \mu \mathrm{M}$. Cells were incubated with siRNA in antibiotic-free medium with $2 \%$ FCS for $6 \mathrm{~h}$, after which the medium was refreshed. Cells silenced for $24 \mathrm{p} 3 \mathrm{R}$ or scrambled were further analyzed or incubated with Alexa-546 $\mathrm{Hb} 72 \mathrm{~h}$ after starting transfection, whereas for hepcidin or RLUC silencing cells were analyzed or incubated with $\mathrm{Hb}$ or hemin $24 \mathrm{~h}$ after starting transfection.

To investigate cell death mechanisms, RLUC and Hamp silenced $\mathrm{mCCD}_{\mathrm{cl} 1}$ cells were incubated for $4 \mathrm{~h}$ with $10 \mu \mathrm{M}$ $\mathrm{Hb}$ or hemin alone or in combination with $40 \mu \mathrm{M}$ Necrostatin-1 (Nec-1, N9037, Sigma-Aldrich), $20 \mu \mathrm{M}$ Ferrostatin (Fer-1, SML0583, Sigma-Aldrich) or $20 \mu \mathrm{M}$ zVADfmk (ALX-260-020-m001; ENZO).

\section{RNA isolation and quantitative PCR}

RNA was isolated with TRIzol (Life Technologies), according to manufacturer's instructions.

Quantitative PCR was performed with SYBR Green mastermix (2×; Applied Biosystems) and primers are listed in Supplementary Table 1. Fold change values compared to control or baseline were calculated with the $2^{\wedge-\Delta \Delta c \mathrm{~T}}$ formula.

\section{Immunostaining}

Cells were washed with PBS and fixed for 30 min with $4 \%$ paraformaldehyde, permeabilized with $1 \%$ sodium dodecyl sulfate for $15 \mathrm{~min}$ and blocked with $1 \%$ bovine serum albumin for $1 \mathrm{~h}$ at RT. Primary antibody against hepcidin (Abcam ab30760) and the N-terminus of $24 \mathrm{p} 3 \mathrm{R}^{31}$ were both diluted 1:100 in blocking solution and incubated overnight at $4{ }^{\circ} \mathrm{C}$. The second antibody (Goatanti rabbit, Invitrogen A-11008) was incubated for $1 \mathrm{~h}$ at RT diluted 1:600. DAPI ( $300 \mathrm{nM}$ for $5 \mathrm{~min}$ ) was used to counterstain nuclei. Hepcidin staining was visualized using a Zeiss ApoTome.2 microscope and imaged using Axiovision 4.8.

\section{Oxidative stress and cell death staining}

CellROX Green reagent (Molecular Probes by Life Technologies C10444) was used according to manufacturer's instructions. Briefly, cells were incubated with CellRox Green reagent for $30 \mathrm{~min}$ at $37^{\circ} \mathrm{C}$, fixed, permeabilized and counterstained with DAPI as described above.

Cell death was visualized with Annexin V-FITC and propidium iodide (PI) staining (both from Abcam ab14085). Cells were incubated with both dyes for $5 \mathrm{~min}$ in the dark, fixed and counterstained with DAPI or $0.8 \mu \mathrm{g} / \mathrm{mL}$ Hoechst 33342 .

\section{Annexin V and PI flow cytometry}

Cells were washed with PBS and harvested using trypsin. Cell pellets were incubated with binding buffer, Annexin V and PI (ab14085, Abcam) for $5 \mathrm{~min}$ in the dark, fixed in $4 \%$ paraformaldehyde for $10 \mathrm{~min}$ and, finally, dissolved in PBS. Annexin V and PI signal were measured on a FACScalibur flow cytometer (BD Bioscience).

\section{Statistical analysis}

Data were presented as mean \pm SEM using GraphPad Prism 5.03 software. Statistically significant differences were calculated using Student's $t$-test or one-way ANOVA with post hoc analysis wherever appropriate. A $p$-value $<0.05$ was considered statistically significant.

\section{Acknowledgements}

We would like to thank Tom Gielkens for performing pilot experiments. The study was partly funded by the Dutch Kidney Foundation (DKF) grants

14OKK03 and 16OKG04 awarded to RvS, the DKF grant 12.81 to DS and the BMBF grant 01DN16039 to FT.

\section{Conflict of interest}

RvS and DS are managing director and medical director, respectively, of the "Hepcidinanalysis.com" initiative, which aims to serve the scientific and medical communities with high-quality hepcidin measurements (www. hepcidinanalysis.com). The remaining authors declare that they have no conflict of interest.

\section{Publisher's note}

Springer Nature remains neutral with regard to jurisdictional claims in published maps and institutional affiliations.

Supplementary Information accompanies this paper at https://doi.org/ 10.1038/s41419-018-0568-z. 
Received: 15 November 2017 Revised: 30 March 2018 Accepted: 6 April 2018 Published online: 10 May 2018

\section{References}

1. Martines, A. M. et al. Iron metabolism in the pathogenesis of iron-induced kidney injury. Nat. Rev. Nephrol. 9, 385-398 (2013).

2. Garcia-Camin, R. M. et al. Molecular mediators of favism-induced acute kidney injury. Clin. Nephrol. 81, 203-209 (2014).

3. Haase, M., Bellomo, R. \& Haase-Fielitz, A. Novel biomarkers, oxidative stress, and the role of labile iron toxicity in cardiopulmonary bypass-associated acute kidney injury. J. Am. Coll. Cardiol. 55, 2024-2033 (2010).

4. Moreno, J. A. et al. AKI associated with macroscopic glomerular hematuria: clinical and pathophysiologic consequences. Clin. J. Am. Soc. Nephrol. 7, 175-184 (2012).

5. Saraf, S. L. et al. Haemoglobinuria is associated with chronic kidney disease and its progression in patients with sickle cell anaemia. Br. J. Haematol. 164, 729-739 (2014).

6. Vermeulen Windsant, I. C. et al. Hemolysis during cardiac surgery is associated with increased intravascular nitric oxide consumption and perioperative kidney and intestinal tissue damage. Front. Physiol. 5, 340 (2014).

7. Vermeulen Windsant, I. C. et al. Hemolysis is associated with acute kidney injury during major aortic surgery. Kidney Int. 77, 913-920 (2010).

8. Eshbach, M. L., Kaur, A., Rbaibi, Y., Tejero, J. \& Weisz, O. A. Hemoglobin inhibits albumin uptake by proximal tubule cells: implications for sickle cell disease. Am. J. Physiol. Cell. Physiol. 312, C733-C740 (2017).

9. Gburek, J. et al. Megalin and cubilin are endocytic receptors involved in renal clearance of hemoglobin. J. Am. Soc. Nephrol. 13, 423-430 (2002).

10. Gozzelino, R. \& Soares, M. P. Coupling heme and iron metabolism via ferritin $\mathrm{H}$ chain. Antioxid. Redox Signal. 20, 1754-1769 (2014).

11. Billings, F. Tt, Ball, S. K., Roberts, L. J. 2nd \& Pretorius, M. Postoperative acute kidney injury is associated with hemoglobinemia and an enhanced oxidative stress response. Free. Radic. Biol. Med. 50, 1480-1487 (2011).

12. Dixon, S. J. et al. Ferroptosis: an iron-dependent form of nonapoptotic cell death. Cell 149, 1060-1072 (2012).

13. Adedoyin, O. et al. Heme oxygenase-1 mitigates ferroptosis in renal proximal tubule cells. Am. J. Physiol. Renal. Physiol. ajprenal000442017 https://doi.org/ 10.1152/ajprenal.00044.2017 (2017). [Epub ahead of print].

14. Linkermann, A. et al. Regulated cell death in AKI. J. Am. Soc. Nephrol. 25 2689-2701 (2014).

15. Muller, T. et al. Necroptosis and ferroptosis are alternative cell death pathways that operate in acute kidney failure. Cell. Mol. Life. Sci. 74, 3631-3645 (2017).

16. Deuel, J. W. et al. Hemoglobinuria-related acute kidney injury is driven by intrarenal oxidative reactions triggering a heme toxicity response. Cell Death Dis. 7, e2064 (2016).

17. Homsi, E., Janino, P. \& de Faria, J. B. Role of caspases on cell death, inflammation, and cell cycle in glycerol-induced acute renal failure. Kidney Int. 69, 1385-1392 (2006).

18. Fortes, G. B. et al. Heme induces programmed necrosis on macrophages through autocrine TNF and ROS production. Blood 119, 2368-2375 (2012).

19. Singla, S. et al. Hemin causes lung microvascular endothelial barrier dysfunction by necroptotic cell death. Am. J. Respir. Cell. Mol. Biol. 57, 307-314 (2017).

20. Sukumari-Ramesh, S. et al. Astrocyte-derived glutathione attenuates hemininduced apoptosis in cerebral microvascular cells. Glia 58, 1858-1870 (2010).

21. Laird, M. D., Wakade, C., Alleyne, C. H. Jr. \& Dhandapani, K. M. Hemin-induced necroptosis involves glutathione depletion in mouse astrocytes. Free Radic. Biol. Med 45, 1103-1114 (2008).

22. Sarhan, M., von Massenhausen, A., Hugo, C., Oberbauer, R. \& Linkermann, A Immunological consequences of kidney cell death. Cell Death Dis. 9, 114 (2018).

23. Billings, F. Tt, Yu, C., Byrne, J. G., Petracek, M. R. \& Pretorius, M. Heme oxygenase-1 and acute kidney injury following cardiac surgery. Cardiorenal Med. 4, 12-21 (2014).

24. Nath, K. A. et al. Heme protein-induced chronic renal inflammation: suppressive effect of induced heme oxygenase-1. Kidney Int. 59, 106-117 (2001).

25. Jaenike, J. R. \& Schneeberger, E. E. The renal lesion associated with hemoglobinemia. II. Its structural characteristics in the rat. J. Exp. Med. 123, 537-545 (1966).

26. Zager, R. A. Rhabdomyolysis and myohemoglobinuric acute renal failure. Kidney Int. 49, 314-326 (1996).
27. Khalighi, M. A., Henriksen, K. J., Chang, A. \& Meehan, S. M. Intratubular hemoglobin casts in hemolysis-associated acute kidney injury. Am. J. Kidney Dis. 65, 337-341 (2015).

28. Zager, R. A. \& Gamelin, L. M. Pathogenetic mechanisms in experimental hemoglobinuric acute renal failure. Am. J. Physiol. 256, F446-F455 (1989).

29. van Swelm, R. P. et al. Renal handling of circulating and renal-synthesized hepcidin and its protective effects against hemoglobin-mediated kidney injury. J. Am. Soc. Nephrol. 27, 2720-2732 (2016).

30. Dizin, E. et al. Albuminuria induces a proinflammatory and profibrotic response in cortical collecting ducts via the $24 \mathrm{p3}$ receptor. Am. J. Physiol. Ren. Physiol. 305, F1053-F1063 (2013).

31. Langelueddecke, C. et al. Lipocalin-2 (24p3/neutrophil gelatinase-associated lipocalin (NGAL)) receptor is expressed in distal nephron and mediates protein endocytosis. J. Biol. Chem. 287, 159-169 (2012).

32. Bao, G. et al. Iron traffics in circulation bound to a siderocalin ( $\mathrm{Ngal}$ )-catechol complex. Nat. Chem. Biol. 6, 602-609 (2010).

33. Cabedo Martinez, A. I. et al. Biochemical and structural characterization of the interaction between the siderocalin NGAL/LCN2 (neutrophil gelatinaseassociated lipocalin/lipocalin 2) and the N-terminal domain of its endocytic receptor SLC22A17. J. Biol. Chem. 291, 2917-2930 (2016).

34. Devireddy, L. R., Hart, D. O., Goetz, D. H. \& Green, M. R. A mammalian siderophore synthesized by an enzyme with a bacterial homolog involved in enterobactin production. Cell 141, 1006-1017 (2010).

35. Haase-Fielitz, A. et al. Urine hepcidin has additive value in ruling out cardiopulmonary bypass-associated acute kidney injury: an observational cohort study. Crit. Care. 15, R186 (2011).

36. Ho, J. et al. Urinary hepcidin-25 and risk of acute kidney injury following cardiopulmonary bypass. Clin. J. Am. Soc. Nephrol. 6, 2340-2346 (2011).

37. Prowle, J. R. et al. Greater increase in urinary hepcidin predicts protection from acute kidney injury after cardiopulmonary bypass. Nephrol. Dial. Transplant. 27, 595-602 (2012).

38. Scindia, Y. et al. Hepcidin mitigates renal ischemia-reperfusion injury by modulating systemic iron homeostasis. J. Am. Soc. Nephrol. 26, 2800-2814 (2015).

39. Houamel, D. et al. Hepcidin as a major component of renal antibacterial defenses against uropathogenic Escherichia coli. J. Am. Soc. Nephrol. 27, 835-846 (2016)

40. Kulaksiz, $H$. et al. The iron-regulatory peptide hormone hepcidin: expression and cellular localization in the mammalian kidney. J. Endocrinol. 184, 361-370 (2005).

41. Devireddy, L. R., Teodoro, J. G., Richard, F. A. \& Green, M. R. Induction of apoptosis by a secreted lipocalin that is transcriptionally regulated by $\mathrm{LL}-3$ deprivation. Science 293, 829-834 (2001).

42. Courselaud, B. et al. C/EBPalpha regulates hepatic transcription of hepcidin, an antimicrobial peptide and regulator of iron metabolism. Cross-talk between C/EBP pathway and iron metabolism. J. Biol. Chem. 277, 41163-41170 (2002).

43. Wang, X. Z. et al. Signals from the stressed endoplasmic reticulum induce C/ EBP-homologous protein (CHOP/GADD153). Mol. Cell. Biol. 16, 4273-4280 (1996).

44. Haddad, J. J. Antioxidant and prooxidant mechanisms in the regulation of redox(y)-sensitive transcription factors. Cell. Signal. 14, 879-897 (2002).

45. Lang, D., Reuter, S., Buzescu, T., August, C. \& Heidenreich, S. Heme-induced heme oxygenase-1 (HO-1) in human monocytes inhibits apoptosis despite caspase-3 up-regulation. Int. Immunol. 17, 155-165 (2005).

46. Oliveira, S. J. et al. ER stress-inducible factor CHOP affects the expression of hepcidin by modulating C/EBPalpha activity. PLOS. ONE. 4, e6618 (2009).

47. Figueiredo, R. T. et al. Characterization of heme as activator of Toll-like receptor 4. J. Biol. Chem. 282, 20221-20229 (2007).

48. Belcher, J. D. et al. Heme triggers TLR4 signaling leading to endothelial cell activation and vaso-occlusion in murine sickle cell disease. Blood 123, 377-390 (2014).

49. Wolfs, T. G. et al. In vivo expression of Toll-like receptor 2 and 4 by renal epithelial cells: IFN-gamma and TNF-alpha mediated up-regulation during inflammation. J. Immunol. 168, 1286-1293 (2002).

50. Nath, K. A. et al. The Role of TLR4 signaling in the nephrotoxicity of heme and heme proteins. Am. J. Physiol. Renal. Physiol. ajprenal004322017 https://doi.org/ 10.1152/ajprenal.00432.2017 (2017). [Epub ahead of print].

51. Martin-Sanchez, D. et al. Ferroptosis, but not necroptosis, is important in nephrotoxic folic acid-induced AKI. J. Am. Soc. Nephrol. 28, 218-229 (2017). 
52. Homsi, E., Andreazzi, D. D., Faria, J. B. \& Janino, P. TNF-alpha-mediated cardiorenal injury after rhabdomyolysis in rats. Am. J. Physiol. Ren. Physiol. 308, F1259-F1267 (2015).

53. Linkermann, A. et al. Two independent pathways of regulated necrosis mediate ischemia-reperfusion injury. Proc. Natl. Acad. Sci. USA 110, 12024-12029 (2013).

54. Dixon, S. J. et al. Pharmacological inhibition of cystine-glutamate exchange induces endoplasmic reticulum stress and ferroptosis. elife 3, e02523 (2014).

55. Zhu, P. et al. Ripk3 promotes ER stress-induced necroptosis in cardiac IR injury: a mechanism involving calcium overload/XO/ROS/mPTP pathway. Redox Biol. 16, 157-168 (2018)

56. Zille, M. et al. Neuronal death after hemorrhagic stroke in vitro and in vivo shares features of ferroptosis and necroptosis. Stroke 48, 1033-1043 (2017).

57. Hsieh, Y. P., Huang, C. H., Lee, C. Y., Lin, C. Y. \& Chang, C. C. Silencing of hepcidin enforces the apoptosis in iron-induced human cardiomyocytes. J. Occup. Med. Toxicol. 9, 11 (2014).

58. Young, G. H. et al. Hemojuvelin modulates iron stress during acute kidney injury: improved by furin inhibitor. Antioxid. Redox Signal. 20, 1181-1194 (2014).

59. Farnaud, S., Patel, A. \& Evans, R. W. Modelling of a metal-containing hepcidin Biometals 19, 527-533 (2006).

60. Farnaud, S. et al. Identification of an iron-hepcidin complex. Biochem. J. 413 553-557 (2008)

61. Gerardi, G. et al. Recombinant human hepcidin expressed in Escherichia coli isolates as an iron containing protein. Blood. Cells Mol. Dis. 35, 177-181 (2005).

62. Serio, K. J., Reddy, K. V. \& Bigby, T. D. Lipopolysaccharide induces 5lipoxygenase-activating protein gene expression in THP-1 cells via a NF-
kappaB and C/EBP-mediated mechanism. Am. J. Physiol. Cell. Physiol. 288 C1125-C1133 (2005)

63. Shehzad, A., Iqbal, W., Shehzad, O. \& Lee, Y. S. Adiponectin: regulation of its production and its role in human diseases. Hormones 11, 8-20 (2012).

64. Millonig, G. et al. Sustained submicromolar $\mathrm{H}_{2} \mathrm{O} 2$ levels induce hepcidin via signal transducer and activator of transcription 3 (STAT3). J. Biol. Chem. 287, 37472-37482 (2012).

65. Zhang, X. et al. Curcumin protects renal tubular epithelial cells from high glucose-induced epithelial-to-mesenchymal transition through Nrf2mediated upregulation of heme oxygenase-1. Mol. Med. Rep. 12, 1347-1355 (2015).

66. Bayele, H. K., Balesaria, S. \& Srai, S. K. Phytoestrogens modulate hepcidin expression by Nrf2: implications for dietary control of iron absorption. Free. Radic. Biol. Med. 89, 1192-1202 (2015).

67. Vecchi, C. et al. ER stress controls iron metabolism through induction of hepcidin. Science 325, 877-880 (2009).

68. Nemeth, E. et al. IL- 6 mediates hypoferremia of inflammation by inducing the synthesis of the iron regulatory hormone hepcidin. J. Clin. Invest. 113, 1271-1276 (2004)

69. Chen, W., Wang, X., Huang, L. I. \& Liu, B. O. Hepcidin in non-alcoholic fatty liver disease regulated by the TLR4/NF-kappaB signaling pathway. Exp. Ther. Med. 11, 73-76 (2016).

70. Gaeggeler, H. P. et al. Mineralocorticoid versus glucocorticoid receptor occupancy mediating aldosterone-stimulated sodium transport in a novel renal cell line. J. Am. Soc. Nephrol. 16, 878-891 (2005). 